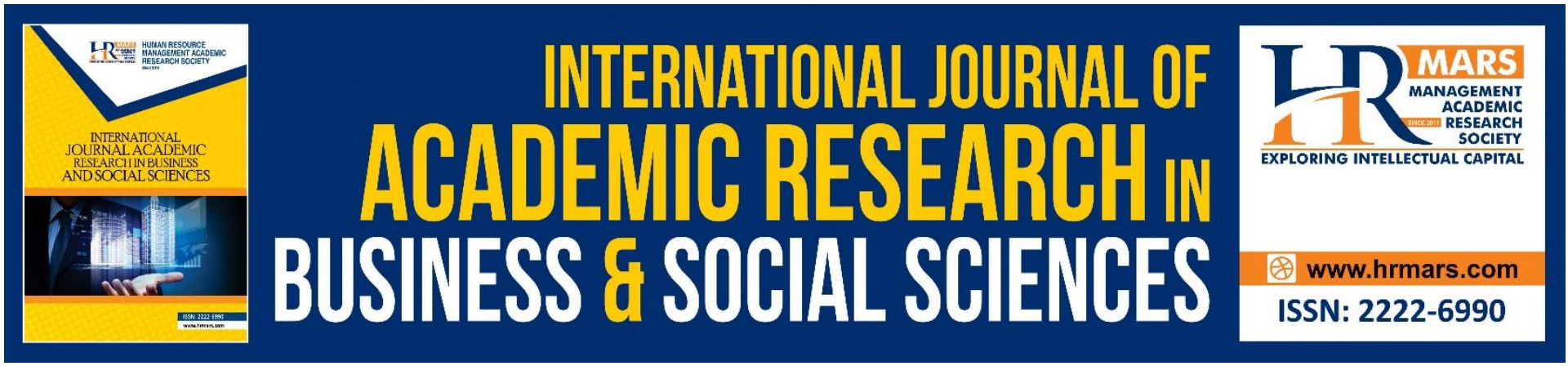

\title{
Malaysian Leaders' Prominence Throughout the Pandemic, and Their Preferences for Social Media and Online Communication
}

Sharfizie Mohd Sharip

To Link this Article: http://dx.doi.org/10.6007/IJARBSS/v11-i10/11343

DOI:10.6007/IJARBSS/v11-i10/11343

Received: 04 August 2021, Revised: 28 August 2021, Accepted: 20 September 2021

Published Online: 13 October 2021

In-Text Citation: (Sharip, 2021)

To Cite this Article: Sharip, S. M. (2021). Malaysian Leaders' Prominence Throughout the Pandemic, and Their Preferences for Social Media and Online Communication. International Journal of Academic Research in Business and Social Sciences, 11(10), 531-539.

Copyright: (c) 2021 The Author(s)

Published by Human Resource Management Academic Research Society (www.hrmars.com)

This article is published under the Creative Commons Attribution (CC BY 4.0) license. Anyone may reproduce, distribute, translate and create derivative works of this article (for both commercial and non-commercial purposes), subject to full attribution to the original publication and authors. The full terms of this license may be seen at: http://creativecommons.org/licences/by/4.0/legalcode

Vol. 11, No. 10, 2021, Pg. 531 - 539

http://hrmars.com/index.php/pages/detail/IJARBSS

Full Terms \& Conditions of access and use can be found at http://hrmars.com/index.php/pages/detail/publication-ethics 


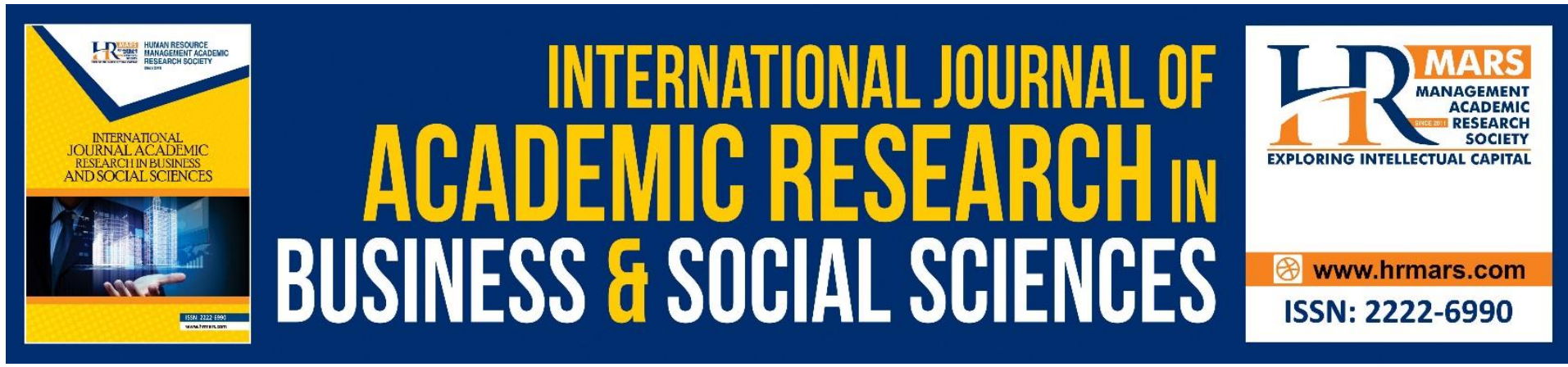

\title{
Malaysian Leaders' Prominence Throughout the Pandemic, and Their Preferences for Social Media and Online Communication
}

\author{
Sharfizie Mohd Sharip \\ Universiti Teknologi MARA, Cawangan Negeri Sembilan, Kampus Rembau, Malaysia
}

\begin{abstract}
The COVID-19 pandemic has forever altered the leadership in numerous institutions worldwide including those in Malaysia. Now more than ever, the spotlight is firmly planted on leaders who are expected to deliver accurate public information via proper channels. The usage of various social media platforms promotes the transmission of information to the surrounding community, and social media is increasingly viewed as a medium that is extremely near to the community. The pace with which information must be conveyed to the public is also affected by the pandemic scenario. Indirectly, these new norms have influenced and transformed how leaders lead.
\end{abstract}

\section{Introduction}

The society's reliance on social media is progressively growing each day. What was once a platform mainly for socialization, social media has now evolved into becoming the primary means for disseminating vital information. At the back of the ongoing pandemic, social media has become the official medium for disseminating updates on the status of cases and rates of infection. Formal channels such as newspapers or news broadcasts seem to have taken a back seat. With such development, national leaders must take heed and begin to utilize social media more effectively in communicating daily updates about the current situation.

Jabatan Perangkaan Malaysia (2021) indicated that Internet usage among Malaysians aged 15 and above increased by 5.4 percent i.e. from 84.2 percent in 2019 to 89.6 percent in 2020; additionally, social media usage is the most popular online activity among the users during the said period. This demonstrates that during the pandemic, the general public prefers to use social media to connect directly with content providers, apply checklists, and perform large-scale evaluations at a quick rate. Hence, to ensure accurate and reliable information delivery by leaders via social media, the selected platforms must be those that are widely utilized by the people.

Research on how leaders utilize social media to disseminate daily updates about the pandemic is still in its infancy. Goel and Sharma (2021) focused on analyzing the usage of Twitter by leaders for the aforementioned purpose. Rufai and Bunce (2020) also focused on the usage of Twitter, but narrowed it down to the Group of Seven (G7) international leaders regardless of the content they chose to post. However, these researches were conducted in 
the context of Western countries. This current study hence sets out to examine the prominence of Malaysian leaders in battling the pandemic, and their tendency to use social media and online communication for that purpose.

\section{Leaders in Malaysia}

Since the beginning of the pandemic, regular updates about the country's health situation have been the most eagerly awaited information by the general Malaysian public. This is because the status of the country's health determines the operational ability of the various industries in the country.

September 20, 2020 marked the beginning of the third wave of the COVID-19 pandemic in Malaysia. The total number of COVID-19 cases increased by 161 percent in six weeks i.e. from 32,505 on November 1, 2020 to 84,846 on December 14, 2020 including a 68 percent increase in deaths (Ministry of Health Malaysia, 2021). The movement control order (MCO) issued by the government authorized only certain industries to operate for specified hours according to the set standard operating procedures.

Several ministries stood out for their significant roles in combatting the pandemic including the Ministry of Health, the Ministry of Internal Security, the Ministry of Education, the Ministry of Human Resources, and The National COVID-19 Immunisation Programme which were entrusted to provide the public with relevant information. To ensure that such information reaches the general public, it is critical for each of the leaders to give accurate and timely statements throughout this period. The utilization of relevant social media channels streamlines this process.

\section{Leader in the Ministry of Health}

The leader in the Ministry of Health is responsible for keeping the Malaysian public informed about the daily status of COVID-19 infections in the country including deaths, as well as health regulations that must be obeyed by everyone in order to curb the infection rate.

According to the Director-General of Health Tan Sri Dr Noor Hisham Abdullah, the rapid increase in COVID-19 cases since early April has posed a significant strain on the country's healthcare system. As such, he urged the community to limit their movements to prevent the pandemic from spreading further (Bernama, 2021b). He stated that breaking the infection cycle is a shared responsibility, and that all Malaysians are now on the front lines. He gave out constant reminders for the public to use face masks especially in crowded spaces. In a more recent development, he strongly advised the public to wear double masks and a face shield particularly in high-risk locations (Hilmi, 2021). According to him, "it is more effective to use a 'double face mask' which may filter out more than 95 percent of the virus, especially in highrisk public places like hospitals". The widespread photo of the leader on social media wearing two face masks and a face shield emphasized the message (Raiham, 2021). 


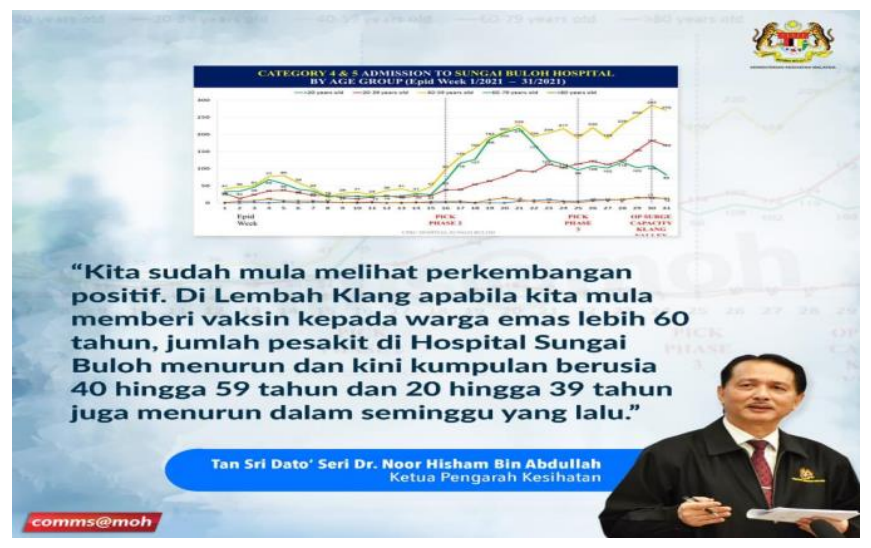

Diagram 1: Sample of content sharing by the leader in the health sector from their Facebook account

Additionally, the Ministry of Health is also responsible for addressing mental issues that have become increasingly prevalent since the start of the pandemic. Certain people are at a higher risk of suffering from depression, particularly when isolated from their family and friends. If not adequately diagnosed and treated, the situation could lead to risks of suicide. According to the Royal Malaysia Police, 631 suicide cases were recorded in 2020 as compared to 609 in 2019, and a total of 336 suicide incidents as of March 2021 (Atiqah, 2021). The leader in the health sector is responsible for publicising the Ministry's mental health and psychosocial support programs which address social factors such as job loss, loss of income, relationship problems, negative perceptions, fear of infection, and workplace issues.

The usage of social media by health leaders is deemed appropriate for the current situation. Based on observations performed during the third wave of COVID-19 transmission in Malaysia between May and August 2021, related notifications were mostly disseminated using social media platforms such as Facebook, Instagram, and Twitter. A search on the Ministry of Health's Facebook account revealed that a large number of users would leave comments immediately when a status is posted; this shows that the general public is constantly anticipating information from the ministry. During the observation period, the summary of new death cases posted on the Ministry's Facebook page on August 29, 2021 received nearly 900,000 comments from users of the social networking site, whilst another report on new death cases posted on August 24 gained 19,000 shares. The majority of social media users utilise the comment section to reply to the leader's message. Some netizens expressed their support, while others provided feedback requesting clarification or interpretation from the government on the subject of delivery.

\section{Leader in the Ministry of Home Affairs}

The leader of this ministry is responsible for announcing any changes to the rules and regulations of the movement control order (MCO) i.e. another piece of information that is eagerly awaited by the public. Throughout the pandemic thus far, the Malaysian government had implemented the MCO in several phases namely the Recovery Movement Control Order (RMCO), the Enhanced Movement Control Order (EMCO), and the Conditional Movement Control Order (CMCO).

Those staying in regions under the general MCO are prohibited from crossing over to other districts and states without the authorization of the PDRM. The number of passengers in private vehicles, taxis, and e-hailing services is also limited to only three (3) individuals 
including the driver. For those staying in regions under the RMCO, movements within the region is permitted whilst movements to other RMCO, MCO, CMCO and EMCO regions is prohibited. The number of passengers in private vehicles is based on the vehicle's capacity. High-risk adults and children are not encouraged to enter crowded areas.Meanwhile, the standard operating procedure (SOP) for regions under the EMCO stipulates that only one member of the household is permitted to go out to buy food, medication, and other necessities, and that only essential services are permitted to operate. Citizens in the EMCO region are also prohibited from leaving their house for activities other than those authorized by the PDRM, and from bringing outsiders into the region. Finally, in CMCO regions, all commercial and industrial sectors as well as government departments are allowed to operate. Movements for healthcare and emergency purposes such as death in the family are also allowed. However, individuals within the region are not allowed to leave the territory for reasons other than approved activities.

The leader usually makes announcements regarding the implementation of various control orders based on the number of cases in the state. Extreme measures are taken in states with rising number of cases, such as implementing stricter control regulations like the EMCO. Notice of the control order is distributed via social media and the Ministry's website.

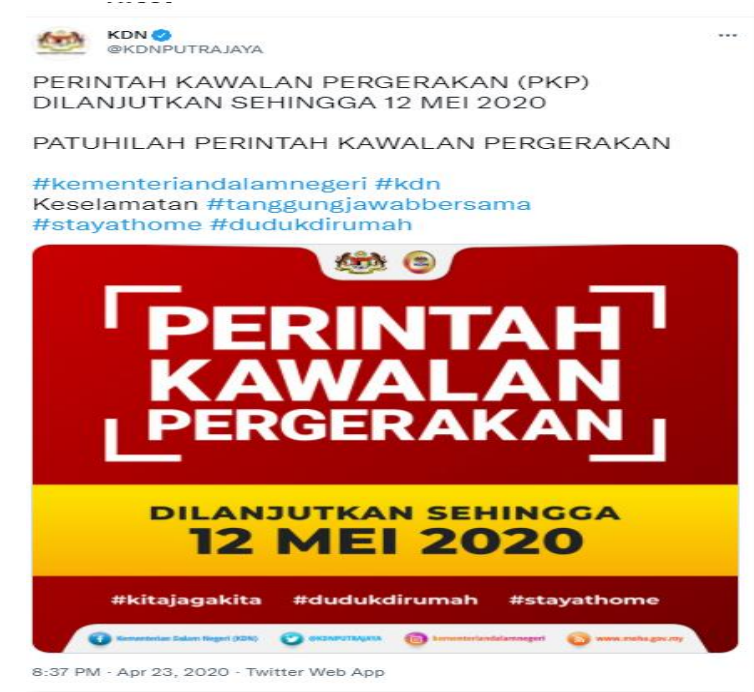

Diagram 2: Sample of content sharing by the ministry of home affair from their Tweeter account

The Ministry has several social media platforms with substantial numbers of followers i.e. Facebook with 525,495 followers, Telegram with 8583 subscribers, Instagram with over 120,000 followers, and Twitter with 428,500 followers. An MCO-related post made on May 12, 2021 gained numerous responses requesting the leader to consider re-opening the economic sector as soon as possible. The leader took heed of these input by considering it in its subsequent decision. Hence, social media may offer the leader a platform to gain insights about the people's general concerns regarding the current situation. This in turn helps the leader in making the best decision for the people's well-being.

\section{Leader in the Ministry of Education}

Malaysia's educational system has been directly affected by the pandemic. Due to the rapid spread of the disease, the Ministry of Education (MOE) and the Ministry of Higher Education 
(MOHE) have agreed to close down schools and higher education institutions nationwide (Rohani, 2021). With the implementation of the MCO on March 18, 2020, the Home-Based Teaching and Learning initiative was implemented as an alternative to the traditional learning system (Goliong et al., 2020). Public and private institutions of higher learning (IPT) also initiated online courses. Universiti Teknologi MARA (UiTM) implemented the Blended Learning (BL) approach and demonstrated that the adoption of this methodology is not a problem for their students (Kechil et al., 2017). The goal of BL is to remove the need for classroom education by combining face-to-face and online learning, an approach that university students generally do not find difficult to adapt to. However, this method was found to be rather problematic in the context of primary and secondary school students due to various limitations such as the instructors' online instructional design abilities, distance teaching skills, and teachers' technological and pedagogical material understanding capabilities (Siti Nur Diyana, 2021). On top of that, there are also considerations related to the parents' readiness and ability to support their children's online learning, as well as the students' own emotional and social development.

The Ministry of Education made significant use of its social media platforms to interact with the public throughout the pandemic. The Ministry publicised its programmes and relayed announcements via its Facebook account which has 1,184,578 followers, its Instagram account with 183,000 followers, and its Twitter account with 136,400 followers. Students and parents are expecting changes in school or university entrance schedules and other education-related activities due to the current situation. Thus, the leader of education chooses the platform of social media to disseminate the latest updates. This is supported by the fact that most university students have at least one social media account which ensures that the relayed information is delivered to the target audience. In a statement posted on its Facebook page on August 15, 2021, the leader stated that student safety would be prioritized in every decision made by the MOE before deciding to re-open schools and colleges.

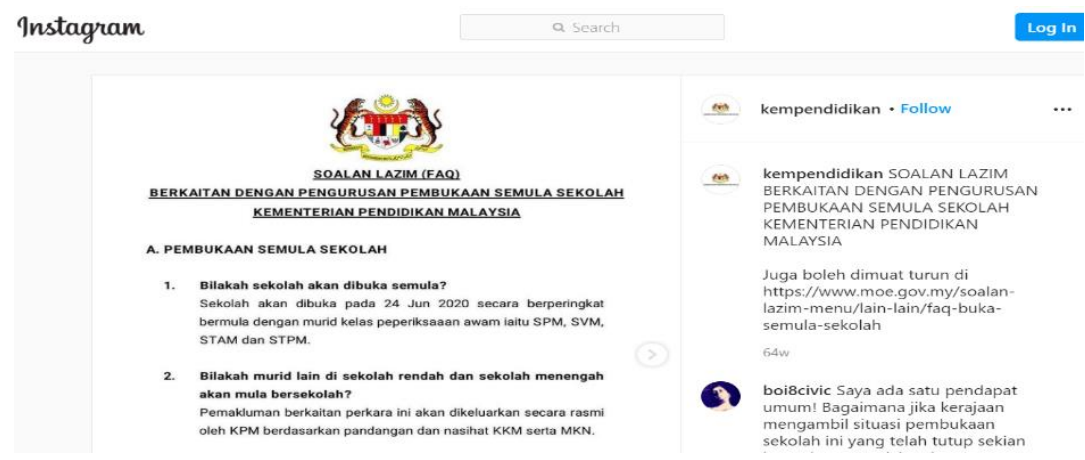

Diagram 3: Sample content sharing by leader of education: MOE decision on school openings from their Instagram account

On top of the Home-Based Teaching and Learning initiative, the MOE also developed innovative programs that make it easier for children to learn through television. The government created the DidikTV KPM, a dedicated channel for educational TV broadcasts from 7 a.m. to 12 a.m. every day ( Noraina \& Yusmizal, 2021). Updates on the programmed schedules as well as the topics and courses to be covered are shared on social media sites such as Facebook. This is a great initiative for students who do not have the proper infrastructure i.e. gadget and internet connectivity to participate in the Home-Based Teaching and Learning program. 


\section{Leader in the Ministry of Human Resources}

Throughout the implementation of the MCO, the Human Resource Department has been tasked to disseminate information related to employers and workers. The Ministry of Human Resources had issued a directive for employers to ensure that employee attendance at the workplace is at a maximum capacity, and that employees must record their daily attendance through the MySejahtera app throughout the First Phase i.e. from June 1 to June 14, 2021 (Jabatan Tenaga Kerja, 2021). Employers should also provide hand sanitizers and mechanisms for checking the body temperature of employees on a daily basis. Employees must strictly adhere to the COVID-19 Preventative of Place Work Safe Working Protocols issued by the Department of Occupational Safety and Health (DOSH) which include the wearing of face masks. They must also adhere to the COVID-19 prevention procedures specified by the $\mathrm{MOH}$ or National Security Council from time to time.

The Ministry of Health has given the Department of Labor for Peninsular Malaysia (JTKSM) and the Department of Occupational Safety and Health (DOSH) under the Ministry of Human Resources (MOHR) the authority to issue compounds under the Prevention and Control of Infectious Diseases Act [Act 342] as of June 1, 2021. The HR ministers are hence responsible for disseminating information regarding the Work from Home initiative as well as other related policies for employers and employees. However, according to Noorazura (2021), some companies refuse to comply with the Work form Home mandate with 78 incidents of such recorded. An investigation paper was opened under the Minimum Standards of Housing, Accommodation and Employee Facilities Act 1990 (Amendment) 2019 (Act 446) against employers for various offenses committed since February (Bernama, 2021a).

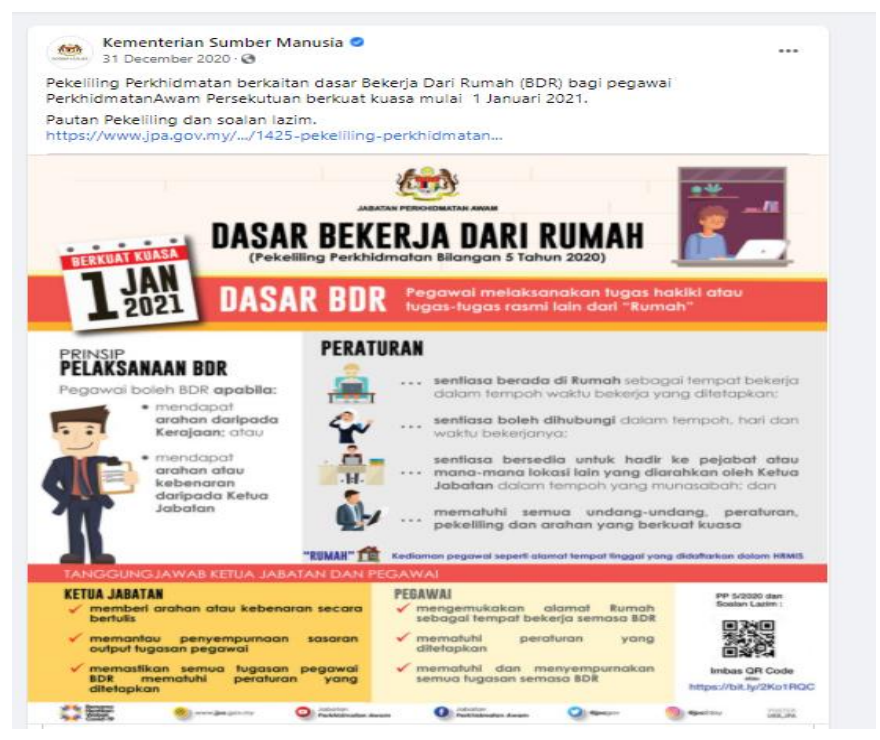

Diagram 4 : Sample content sharing by the leader in the human resource sector from their Facebook account

When it comes to social media, Facebook triumphs over Instagram in terms of platform preference. At present, the Ministry of Human Resources has 255,221 Facebook followers, and all the latest updates are published directly to its Facebook account. The ministry also utilizes social media to distribute information about the KSM Departments \& Agencies Hotline, which is operational during the MCO, to enable the public to make relevant reports throughout the control period. 


\section{Leader of The National COVID-19 Immunisation Programme}

Jawatankuasa Khas Jaminan Akses Bekalan Vaksin (JKJAV) was established to ensure that the supply of COVID-19 vaccines to the country can be obtained immediately and safely. The Ministry of Science, Technology and Innovation (MOSTI) and the Ministry of Health Malaysia $(\mathrm{MOH})$ serve as the Main Committees in planning, implementing, and monitoring the overall strategy for COVID-19 vaccine supply until the implementation of the immunisation program is fully completed (JKJAV, 2021). This committee has 168,248 followers on Facebook, 232,800 followers on Twitter, and 5,970 followers on You Tube.

The leader of this division is responsible for making periodic statements regarding the vaccination status in Malaysia as well as informing about the vaccination rate in each state. This information is also published on the committee's social media platforms for regions where a new vaccination facility is launching. The community may also check the walk-in vaccination information list on these platforms.

\section{Conclusion}

COVID-19 has put the leadership of multi-sector organizations worldwide to the test. The uncertainties posed by the pandemic render it difficult for businesses and communities to plan ahead; hence, leaders must change their leadership styles. Now more than ever, they need to be extra prepared and proactive, ready to lead the people in facing the challenges that lie ahead (Zaleha, 2021).

The leaders' communication planning is viewed as extremely important. The way they communicate is critical in ensuring that government efforts to curb infection rates are effective. Their chosen media channel to disseminate information must be consistent with contemporary technical developments. Overall, on top of changing the way information is communicated, the pandemic has also transformed the way leaders lead.

\section{References}

Bernama. (2021a). Majikan tidak benarkan BDR kekal aduan tertinggi Artikel Penuh. Sinar Harian.

Bernama. (2021b, May 18). Kes naik mendadak, Dr Noor Hisham rayu masyarakat amal kawalan pergerakan kendiri. Malaysia Kini. https://www.malaysiakini.com/news/575137

Goel, R., \& Sharma, R. (2021). Studying leaders \& their concerns using online social media during the times of crisis - A COVID case study. Social Network Analysis and Mining, 11(1), 1-12. https://doi.org/10.1007/s13278-021-00756-w

Goliong, L., Kasin, A., Johnny, M., \& Yulip, N. G. (2020). Cabaran Pelaksanaan Pengajaran dan Pembelajaran Jarak Jauh ( PDPCJJ) Semasa Perintah Kawalan Pergerakan ( PKP). Pejabat Pendidikan Daerah Ranau, 1-15. https://www.academia.edu/43147586/Cabaran_Pelaksanaan_Pengajaran_dan_Pembe lajaran_Jarak_Jauh_PDPCJJ_Semasa_Perintah_Kawalan_Pergerakan_PKP_

Hilmi, M. (2021). COVID-19: Pemakaian dua pelitup muka digalakkan - Dr Noor Hisham. Astro Awani. https://www.astroawani.com/berita-malaysia/covid19-pemakaian-duapelitup-muka-digalakkan-dr-noor-hisham-299311

Jabatan Perangkaan Malaysia. (2021). Penggunaan dan Capaian ICT oleh Individu dan Isi Rumah 2020. https://www.dosm.gov.my/v1/uploads/files/5_Gallery/2_Media/4_Stats\%40media/4Press_Statement/2021/20210412-Kenyataan_Media- 
Penggunaan_dan_Capaian_ICT_oleh_Individu_dan_Isi_Rumah_2020.pdf

Jabatan Tenaga Kerja. (2021). SOALAN LAZIM (FAQ) MENGENAI PEKERJAAN SEMASA

PERINTAH PENUTUPAN PENUH SEKTOR SOSIAL DAN EKONOMI (TOTAL LOCKDOWN) KEMENTERIAN SUMBER MANUSIA.

https://jtksm.mohr.gov.my/images/novel_coronavirus/soalan_lazim/FAQ KSM PKP

3_2.6.2021.pdf

JKJAV. (2021). About JKJAV : Jawatankuasa Khas Jaminan Akses Vaksin Covid-19. https://www.vaksincovid.gov.my/tentang-jkjav/

Kechil, R., Mydin, A. M., Anisha, W., Mohammad, W., Libasin, Z., Komputer, J. S., Matematik, D., Teknologi, U., Cawangan, M., \& Pinang, P. (2017). The Impact of Blended Learning (BL) in UiTM Cawangan Pulau Pinang. International Academic Research Journal of Social Science, 3(1), 239-244. http://www.iarjournal.com/wpcontent/uploads/IARJSS2017_1_239-244.pdf

Kementerian Kesihatan Malaysia. (2021). Gelombang Ketiga Pandemik Covid-19 Di Malaysia. https://covid-19.moh.gov.my/semasa-kkm/122020/gelombang-ketigapandemik-covid-19-di-malaysia

Atiqah, N. S. (2021). Kes bunuh diri meningkat. Berita Harian. https://www.bharian.com.my/berita/nasional/2021/06/833673/kes-bunuh-dirimeningkat

Noorazura, A. R. (2021). JTK keluarkan hampir RM2 juta kompaun. Harian Metro. https://www.hmetro.com.my/mutakhir/2021/07/730125/jtk-keluarkan-hampir-rm2juta-kompaun-metrotv

Raiham, M. S. (2021). Pemakaian "double face mask" digalakkan. Sinar Harian. https://www.sinarharian.com.my/article/139956/BERITA/Semasa/Pemakaian-doubleface-mask-digalakkan

Noraina, R. R., \& Yusmizal, D. A. (2021). PM lancar DidikTV. My Metro. https://www.hmetro.com.my/utama/2021/02/675273/pm-lancar-didiktv-metrotv

Rohani, A. G. (2021). Pandemik Covid19 dan Norma Baru dalam Pendidikan Malaysia. Paper Knowledge. Toward a Media History of Documents.

Rufai, S. R., \& Bunce, C. (2020). World leaders' usage of twitter in response to the COVID-19 pandemic: A content analysis. Journal of Public Health (United Kingdom), 42(3), 510516. https://doi.org/10.1093/pubmed/fdaa049

Diyana, S. N. M. (2021). Teliti cabaran dihadapi guru, murid dalam PdPR. Berita Harian. https://www.bharian.com.my/rencana/minda-pembaca/2021/05/812576/teliticabaran-dihadapi-guru-murid-dalam-pdpr

Zaleha, Y. (2021). Era pandemik uji kepemimpinan organisasi. https://www.bharian.com.my/kolumnis/2020/05/687192/era-pandemik-ujikepemimpinan-organisasi 